\title{
THE 110TH ANNIVERSARY OF QUEUEING THEORY: ITS APPLICATIONS IN THE MILITARY
}

\author{
Nebojša V. Nikolić \\ University of Defence in Belgrade, Strategic Research Institute, \\ Defense Studies Section, Belgrade, Republic of Serbia, \\ e-mail: nebojsa.nikolic11@mod.gov.rs, \\ ORCID iD: (i)http://orcid.org/0000-0003-4875-3418
}

DOI: 10.5937/vojtehg67-22460; https://doi.org/10.5937/vojtehg67-22460

FIELD: Logistics

ARTICLE TYPE: Professional Paper

ARTICLE LANGUAGE: English

Abstract:

The aim of the paper is to present selected examples of queueing theory applications to problems in the military and defence domain, to mark the $110^{\text {th }}$ anniversary of queueing theory. The intention was to find and present more works from domestic authors published in a longer period in order to promote the theory in the domestic military and defence circles thus motivating future research related to waiting lines phenomena. In dealing with military queueing phenomena, researchers are usually faced with some specific requirements which involve a multidisciplinary approach. In the queueing theory community, it is recognized that solutions to queueing problems could be reached in three ways: by analytical, numerical and simulation methods. Not all queueing problems are solvable by analytics or by numerical mathematics and, for such problems in particular, simulation methodology is a resolving tool.

Key words: military application, queueing theory, simulation, modeling, logistics, combat, command \& control, transient regime, overloading.

\section{Introduction}

The $110^{\text {th }}$ anniversary of queueing theory (Erlang, 1909) is a good opportunity to make an overview of its application in various fields.

ACKNOWLEDGMENT: This work was partially supported by the Ministry of Education and Science of the Republic of Serbia under Interdisciplinary Project No.III-47029 (title: "Cost Effective Selection of New Technologies and Concepts of Defence Through Social Reforms and Strategic Orientations of Serbia in $21^{\text {st }}$ Century). 
The historical development of queueing theory has been presented in short by Nikolić (2008). This paper presents some applications of queueing theory for various issues in the military and defence as well as some actual trends and prospects for future research. Queueing theory has been recognized for a long time as an appropriate scientific discipline for analyzing various problems in the military domain - let us mention works of a few domestic authors (Čubra, 1977), (Rendulić, 1981), (Vojnoizdavački zavod, 1970), (Serbian Armed Forces, 1996).

\section{Military queueing systems}

Queueing theory deals with models of queueing systems (or waiting lines). Capability of queueing theory to be used for considering various problems in the military domain comes form a simple definition of a queueing system: "Any system in which arrivals place demands upon a finite-capacity resources may be termed a queueing system" (Kleinrock, 1975). Following this definition and applying it in the military domain, one can find that there are many military situations, processes and systems which could be described, presented, modeled and analyzed as queueing systems. In order to be denoted in a short and general term, all real systems, processes and situations from the military and defence domain which can be described as queueing systems are here named "military queueing systems".

There are many kinds of military queueing systems. Classified by their physical nature and characteristics, military queueing systems could be from various military sub-fields, and related to them, as follows:

- Battle situations ("serving" of arriving enemy tanks, rockets, airplanes).

- Command and control processes.

- Decision making (at individual and organizational levels).

- Weapon's systems.

- Technical items.

- Logistics functions (maintenance, transportation, supplies).

- Medical evacuation.

- Facility operations (runway that make "services" to airplane takeoffs and landings; emergency medical department operations; etc).

- Peace missions of the United Nations.

- Administrative processes, etc. 
Queueing system modeling consists of a few steps. The first step in studying any real system intended to be described as a queueing system is abstraction: the components of the considered real system should be recognized as clients or servers; types and intensities of input and output clients flows should be determined, as well as queueing discipline, reliability of servers, patience of clients, etc. In particular cases, a high level of abstraction is needed, for example: arriving airplanes or missiles should not be in a viewable, static "queue", etc.

Successful abstraction leads to a conceptual model. A conceptual model should be understandable to both sides: to experts for a real system, process or situation which is the subject of the study, and to simulation experts who will provide future development and transformation of a conceptual model towards a clearly structured problem from the point of view of a methodological tool or a theory which will provide its resolution.

On the basis of common sense and supported by various military sub-fields subject matter experts, a minimal set of axioms for military queueing models can be established: (1) Engagement of military queueing systems, particularly in war missions, is finite by time; and, (2) Traffic intensity can be of any value, so there is no logical reason to place any limits on it. These axioms are particularly valid in modern warfare characterized by fast-moving combat situations, fierce by intensity, short by time, and planned with limited resources. Implementing these axioms into the study of queueing systems leads to a question of fidelity in simulation modeling of military queueing systems, as well as in cases when classical queueing theory is used. These axioms contribute to the intensified development of analytical mathematical methods as a basic approach in studying queueing models, but also to the development and application of the other two methodological approaches, i.e. numerical methods and simulation methods (which are, in fact, statistical methods). These three approaches are recognized in the referential literature (Nikolić, 2008), (Worthington, 2009).

In the following section, we offer a number of examples from the military and defence domain where queueing theory was engaged, or at least where the basic concept of queueing modeling is used.

\section{Examples of military applications of queueing theory}

Ballistic missile defence modeling. $\mathrm{Li}$ et al (2016), from the Chinese Air Force Engineering University, presented the simulation modeling and performance analysis of a layered ballistic missile defence 
system as a tandem queueing model of type $M / M / n / n$. They analyzed different variants of tandem queueing systems: with two and three service phases (two and three layers of missile defence systems), and with identical and different defence weapons (variants of identical and different service channels). Also, they considered a few different scenarios with varying input values for the number of total missiles and missile detection probabilities. The overall goal of their work was to model and analyze variants of a ballistic missile defence system in order to find the best option regarding defence effectiveness. They pointed out to the limitations on the exponential nature of the stochastic dynamics of input (arrivals) and output (services) client's streams, and marked a need for future research in regard to other types of arrival and service processes.

Air Defence modeling. Yao and Ma (2017), two researchers from the Chinese Naval Academy at Dalian, modeled an air defence missile weapon system as a queueing system which consists of two phases of servicing by multichannel service facility. They tried to evaluate and compare different options of mixed deployment of anti-aircraft artillery and air defence missile weapons. They described the referent (a real system or process) as a conceptual queueing model and then simplified further analyses by adopting a hypothesis for stationary behavior of the queueing model. The use of queuing theory in air defence modeling has been a subject of research for a long time in many armies including small ones like Serbia's.

Aircraft Sortie Generation Rate. Mao et al (2013), used a multiclass closed queueing network as a model for an analysis of aircraft combat sortie generation rate ("sortie" is a specific military term used to denote a combat mission of a single aircraft, one combat flight). This is a case of modeling the engagement of carrier-based aircraft in combat missions. Due to limited space, short runways and mobility of the main platform, there are many specifics in the operational procedures for sortie generation and a number of consecutive steps for aircraft preparation and launching from the carrier to execute a delivered combat task. In its essence, this process of combat sortie generation could be modeled as a multiphase queueing system (network). Due to different types of aircraft and missions, it is a multiclass service model. In addition, due to a finite number of aircraft on a carrier, it is a closed queueing model. Naturally, these kinds of weapon systems are of primary interest for armies which already have or tend to obtain aircraft carriers. However, it is of interest for all other armies which could be faced with adversary's aircraft carriers. 
Aircraft squadron servicing. Pantić (2002) considered possibilities to apply the queueing theory models in presenting and analyzing servicing activities for a supersonic aircraft squadron in a dispersed formation. The challenge was to investigate the implications of replacing the original fuelers with other types of special vehicles designed for aircraft refueling . The queueing model used was a multichannel service facility with a limited number of waiting rooms and with a simplified assumption that the system operates in a steady state.

Indirect fire weapons systems conceptual modeling. Wheeler (2005), applied the queueing models to study offensive support indirect fire weapons systems. Some others analyzed methodological procedures for analyzing modes of combat use of artillery weapons and consequent impacts on weapons maintenance systems.

Military Command and Control, decision making and staff work. Jovanović (1984), mentioned queueing theory and a simulation of queuing systems as appropriate tools for research of staff works, operations and management. Marković (2000), recognized the values of queueing models for military operations planning and staff functioning. Maksić and Mišković (1997), confirm the value of queueing theory in a list of other methods and tools used for decision making support and for research in the military domain. Leonhard et al (2010), point out the capabilities of queueing theory in the development and analysis concepts of command and control. Also, Athans (1987), one of the most prominent authors in the field of military command and control theory, clearly pointed out the relevancies and appropriateness of the concepts of queueing models and queueing theory to the issues related to perceiving, modeling and analyzing problems from the military command and control domain. Nikolić (2016), presented the reneging queues model as the starting point for developing the general model for command and control processes known as Lawson's Model of C2.

Undersea warfare. Sullivan and Grivell (2003), used queueing models with a set of various probability distributions for investigation in the field of undersea warfare. However, their model and research have potential to be used in other (non-navy) warfare tasks and situations which involve attackers and defenders in a finite time frame and with different types of probability functions.

NBC (nuclear, biological, chemical) decontamination. Forca (1992), presented an organizational process of NBC decontamination as a queueing model (servicing a number of clients with limited resources), and used a simulation methodology to conduct practical calculations in regard to system performances. 
Medical evacuation (MEDEVAC). Mićović (1998) presented a queueing simulation model of military medical evacuation in a combat mission. The queueing model was characterized by multiphase servicing, multiclass clients (clients with different priorities for medical evacuation) and triage rules for a preliminary classification of casualties and assigning appropriate priority levels for evacuation. Jenkins (2017), studied MEDEWAC dispatching policies for casualties evacuation and modeled it as a heterogene multiphase queueing system with three classes of priority clients: priority 1 -Urgent; priority 2 -Priority; priority 3 Routine.

Military hospital pharmacy delivery process performance evaluation. Bahadori et al (2014), conducted a descriptive and analytical study with the use of queueing theory to describe and analyze outpatient pharmacy in a military hospital, with the aim of achieving better performance with some changes in organization and resources. They identified servicing points with low server's utilization (and proposed reduction of service personnel at these points), as well as some bottlenecks where they proposed rational enlargement of service capacity (they proposed multitasking personnel for a few different but very simple operations).

Cadet's mess congestions and food delivery process modeling. Kama and Mankilik (2015), presented an application of queueing theory in a cadet mess of the Nigerian Defence Academy in Kaduna. The initial problems identified were long queues in a cadet mess, particularly during lunch, and consequently poor satisfaction of cadets with mess service. They modeled the mess process, conducted investigation with queueing theory application for more variants, and produced a concrete proposal for appropriate enlargement of specific mess resources.

Military entry control facilities operations. Dwyer (2016) modeled military entry control facilities as a queueing system and investigated how it operates, with the aim of resolving congestion problems concurrently sustaining a high level of service quality regarding security standards in particular.

Maintenance process for military technical items. Military maintenance processes have been extensively studied with many examples related to different contexts, ranging from depot maintenance in peace time conditions to field maintenance in combat missions. Petrović et al (2013), analyzed a maintenance process in a military depot, and used some empirical data for the intensity of service requirements as well as for the service process itself in order to find out weak points in the maintenance process organization. Petković et al 
(1988) point out queueing theory as a methodological tool in considering organizational issues related to the maintenance of technical items. Radošević (1980) used queueing models for maintenance workshops capacity planning connected with reliability levels of technical items. Ćirović (1992) considered maintenance treatment in the early phases of development of military telecommunication equipment.

Technical support of joint tactical units. Military logistics functions of maintenance and supply used to be known in the past as technical support (or technical sustainment). Under this term, many research studies were realized in the last decades of $20^{\text {th }}$ century. Nikolic (1989) offered an extensive study on the efficiency of performing technical support at the level of joint tactical units (brigade) in battle conditions. Branković (1986) used the simulation methods to study a maintenance process modeled as a queueing system in order to get an insight into the performances of maintenance units in battle conditions.

Timely logistics support to military units in operations. McConnel (2018) conducted an extensive study on the problem of dropping equipment readiness due to distribution problems during military operations. The stochastic nature of the requirements for logistics support and varying service response led him to the use of queueing theory.

Some additional examples of various military queueing systems and modeling processes can be found in the literature (e.g. in Shephard et al (1988)), where other methods of operations research were used as well. One good example where a specific military problem was studied by a combined use of queueing theory and other methods of operational research is given by Kang et al (1998), from the Department for Systems Management at the Naval Postgraduate School, Monterey. They considered the naval aircraft maintenance process and presented the relations among the following disciplines: military operations planning, logistic (maintenance and supply), cost analysis, queueing theory, and simulation. Military operations planning assumes taking into account air power which is a dynamic category measured by the level of combat readiness (percentage of "ready-for-use" weapon systems in the unit). Reduction of the maintenance cycle time produces a higher level of operational availability and, consequently, higher combat readiness. Inventory levels of spare parts have a direct influence on the reduction of the maintenance cycle time: if a needed spare part is at hand, it can be used immediately; if not, the item being repaired has to wait for that spare part. On the other hand, a huge amount of spare parts across the inventory system is not a good solution because it costs too much and 
produces other problems such as physical limitations at lower maintenance levels. Modeling of the entire maintenance process leads to a complex queueing model which requires a more appropriate method: simulation modeling (Kang et al, 1998).

\section{Some actual trends and prospects for future research}

What are the prospects of queueing theory application and its development in the future? The best answer to the question could be found in referential sources of scientific information and from recognized experts in the field. Some of such sources, with clear observations about the actual state of the art and good visioning of future development, are referred to in Worthington (2009), and Kingman (2009). Worthington's (2009) findings about the future development could be summarized as follows:

- more dedication to queueing models with non-exponential distributions for demands (arrivals) and servicing;

- more respect for time-dependent behavior of queueing systems;

- more care to more complex queueing models (networks);

- more fidelity in implementing complex relationships among elements inside complex queuing models;

- improving robustness and sensitivity of queueing models;

- more care to the modeling process for queueing models (thinking about "queue modeling as a discipline", (Worthington, 2009).

Kingman (2009) offered an interesting review of the development of queueing theory and indicated the connections of the queueing theory development with problems from the military and defence domains which were describable as queueing models and related to Thomas Saaty, a well-known operations researcher. He also confirms that future development of the theory will be oriented towards problems in complex queueing models (queueing networks), congestion problems, as well as models with non-exponential distributions which are problematic even in simple structure models like the model type: M/G/k (Kingman, 2009).

In order to clarify the connections among the mentioned challenges in queueing theory and corresponding queueing problems in the field of the military and defence issues, we point out the following. Military units in war are not continually engaged. Enemy tanks, rockets and airplanes are not continually in sight during wartime. One attack or defense operation is usually planned and executed for a limited period of time. The observation about the finiteness of reality in the military context is one of the keystone facts which have to be taken into account in military 
modeling. Cases of heavy-traffic, saturation and overloading of service capacity (traffic intensity close to 1 , equal to 1 , and greater than 1), are rarely studied in the literature, but could be of interest for studies of military queueing systems. In the military domain, overloading is often a desired state: overloading enemy's capacity is a traditional condition of victory. Otherwise, one can get a wrong model. However, heavy traffic conditions and overloading can be of interest in civilian matters as well. For an owner of a queueing system, it is very desirable to sustain high utilization of service resources. On the other hand, critical traffic conditions (heavy-traffic, saturation, overloading) sometimes may appear at some points inside a complex queueing system (queueing network), and almost certainly in various kinds of emergency situations when a lot of service requirements can suddenly appear in a relatively short time.

The impact of the transient regime of the military queueing system operation is of particular importance in cases of some real queueing systems, processes and situations. Regarding military queuing systems in combat conditions, the impact of the transient regime was discussed by Nikolić (2008), while more information about the transient phenomenon in queueing behavior could be found in Nikolić (2008) and Kaczynski et al (2012). The importance of the queuing transient phenomenon for other-than-military-systems is confirmed in some novel papers as well (Gindin et al, 2014), (Tsai et al, 2017).

\section{Conclusion}

This paper presents a few examples of the applications of queueing theory in the defence and military domain. The goal is to refresh knowledge and awareness about wide possibilities of military applications of queueing theory at this special moment of the queueing theory anniversary.

Trends and prospects for the future development of queueing theory are in favor on solving challenges which we face when studying military queueing systems.

\section{References}

Athans, M. 1987. Command and control (C2) theory: A challenge to control science. IEEE Transactions on Automatic Control, 32(4), pp.286-293. Available at: https://doi.org/10.1109/tac.1987.1104607.

Bahadori, M.K., Mohammadnejhad, S.M., Ravangard, R., \& Teymourzadeh, E. 2014. Using Queuing Theory and Simulation Model to Optimize Hospital Pharmacy Performance. Iranian Red Crescent Medical Journal, 16(3). Available at: https://doi.org/10.5812/ircmj.16807. 
Branković, Z. 1986. Simulacija upotrebe jedinica za održavanje tehničkih sredstava u borbenim dejstvima. MSc thesis. Zagreb: VVTŠ KoV JNA (in Serbian).

Čubra, N. 1977. Kibernetika u rukovođenju razvojem oružanih snaga.Belgrade: Vojnoizdavački zavod (in Serbian).

Ćirović, M. 1992. Razmatranje održavanja u fazi razvoja elektronskog uređaja. Vojnotehnički glasnik/Military Technical Courier, 40(6), pp.619-626 (in Serbian). Available at: https://doi.org/10.5937/vojtehg9206619c.

Dwyer, J.J. 2016. Analysis of Military Entry Control Point Queueing. MSc thesis in Operations Research. Ohio, USA: Air Force Institute of Technology Wright-Patterson Air Foce Base.

Erlang, A.K., 1909. Sandsynlighedsregning og Telefonsamtaler. Nyt tidsskrift for matematik, 20(B), pp.33-39 (in Danish). Available at: https://www.jstor.org/stable/24528622 [Accessed: 5 July 2019].

Forca, B. 1992. Jedan primer u primeni simulacije procesa u borbenim sistemima. Savremeni problemi ratne veštine, 27, pp.78-92 (in Serbian).

Gindin, S.I., Khomonenko, A.D., \& Matveev, S.V. 2014. Program for probability-time characteristics calculation in multichannel queueing system with "warm-up" and its testing approach. Scientific Review/Hаучное обозрение, 4(19). Available at: https://science-engineering.ru/pdf/2015/1/935.pdf [Accessed: 5 July 2019].

Jenkins, P. 2017. Using Markov Decision Process with Heterogeneous Queueing System to Examine Military MEDEWAC Dispatching Policies. MSc thesis in Operations Research. Ohio, USA: Air Force Institute of Technology Wright-Patterson Air Foce Base.

Jovanović, B. 1984. Uvod u teoriju vojnog rukovođenja.Belgrade: Vojnoizdavački zavod (in Serbian).

Kaczynski, W.H., Leemis, L.M., \& Drew, J.H. 2012. Transient Queueing Analysis. INFORMS Journal on Computing, 24(1), pp.10-28. Available at: https://doi.org/10.1287/ijoc.1110.0452.

Kama, H., \& Mankilik, I. 2015. Application of Queueing Theory in Cadet Mess Administration: A Case Study of Nigerian Defence Academy. Academy Journal of Science and Engineering, 9(1), pp.89-100. Available at: http://www.academyjsekad.edu.ng/vol0901-89-100-AJSE.pdf [Accessed: 5 July 2019].

Kang, K., Gue, K.R., \& Eaton, D.R. 1998. Cycle time reduction for naval aviation depots. In: 1998 Winter Simulation Conference. Proceedings (Cat. No.98CH36274). Institute of Electrical and Electronics Engineers (IEEE), pp.907-912. Dec 13-16. Available at: https://doi.org/10.1109/wsc.1998.745089.

Kingman, J.F.C., 2009. The First Erlang century - and the next. Queueing Systems, 63:3. Available at: https://doi.org/10.1007/s11134-009-9147-4.

Kleinrock, L. 1975. Queueing systems, Volume 1: Theory.New York: John Wiley and Sons. 
Leonhard, R.R., Buchanan, T.H., Hillman, J.L., Nolen, J.M., \& Galpin, T.J. 2010. Concept for Command and Control. John Hopkins APL Technical Digest, 29(2); 157-170. Available at: https://www.jhuapl.edu/Content/techdigest/pdf/V29N02/20-02-Leonhard.pdf [Accessed: 5 July 2019].

Li, L., Liu, F., Long, G., Zhao, H., \& Mei, Y. 2016. Performance Analysis and Optimal Allocation of Layered Defense M/M/N Queueing Systems. Mathematical Problems in Engineering, 2016, pp.1-21. Available at: https://doi.org/10.1155/2016/5915918.

Maksić, R., \& Mišković, R. 1997. Metode i tehnike koje se najčešće primenjuju kao pomoć u odlučivanju i istraživanju u vojnim organizacionim sistemima. Vojno delo, 49(2), pp.70-88 (in Serbian).

Mao, Z., Yu-juan, W., Chao, W., \& Sheng, H. 2013. Analysis on Aircraft Sortie Generation Rate Based on Multi-class Closed Queueing Network. In: Proceedings 2nd International Conference on Computer Science and Electronic Engineering, ICCSEE. pp.1877-1880.

Marković, D. 2000. Priprema operacije kao oblika borbenih dejstava. Novi glasnik, 3-4, pp.19-22 (in Serbian).

McConnel, B.M. 2018. Assessing Uncertainty and Risk in an Expeditionary Military Logistics Network. PhD thesis. Raleigh, North Carolina: Nort Carolina State University

Mićović, B. 1998. Simulacija evakuacije ranjenika. In: SYM-OP-IS 1998: Symposium on Operational Research, Herceg Novi, pp.1025-1028. September 21-24 (in Serbian).

Nikolić, M. 1989. Efikasnost funkcionisanja sistema tehničkog obezbeđenja združenih taktičkih jedinica u oružanoj borbi. Ph.D. thesis. Zagreb: VVTŠ KoV JNA (in Serbian).

Nikolić, N. 2008. Monte Carlo Modeling of Military Queueing Systems Challenge of the Initial Transience.Belgrade: Andrejevic Endowment/Strategic Research Institute.

Nikolić, N., 2016. Reneging Queues Impact on Development of Lawson's Model of Command and Control Processes. In: SYM-OP-IS 2016: Symposium on Operational Research, Tara, Serbia, pp.483-486. September 20-23.

Pantić, T. 2002. Possibility to apply the mass servicing theory method to supersonic aircraft squadron servicing. Vojnotehnički glasnik/Military Technical Courier, 50(6), pp.612-622 (in Serbian). Available at: https://doi.org/10.5937/vojtehg0206612P.

Petković, R., Ćirović, M., \& Kokanović, M. 1988. Organizacija održavanja tehničkih materijalnih sredstava.Zagreb: VVTŠ KoV JNA (in Serbian).

Petrović, V., Mrdak, V., \& Luković, B. 2013. Mass serving theory application to the analysis of maintenance system functioning. Vojnotehnički glasnik/Military Technical Courier, 61(2), pp.159-181 (in Serbian). Available at: https://doi.org/10.5937/vojtehg61-2001.

Radošević, I. 1980. Model masovnog usluživanja pri planiranju kapaciteta tehničkih radionica na bazi pouzdanosti tehničkih materijalnih sredstava. Vojnotehnički glasnik/Military Technical Courier, 28(6), pp.737-742 (in Serbian). 
Rendulić, Z. 1981. Naučnotehnički progres i naoružanje.Belgrade: Vojnoizdavački zavod.

-Serbian Armed Forces. 1996. Metodologija ratne veštine.Belgrade: Serbian Armed Forces, CVŠ VJ Generalštabna škola (in Serbian).

Shephard, R.W., \& et al., 1988. Applied operations research - Examples from defense assessment.New York: Plenum Press.

Sullivan, K., \& Grivell, I. 2003. QSIM: A Quueueing Theory Model with Various Probability Distribution Functions. Technical Report 11.418. Newport, Rhode Island, USA: Naval Undersea Warfare Center Division. 14 March.

Tsai, Y.L., Yanagisawa, D., \& Nishinari, K. 2017. Transient Analysis of a Series Configuration Queueing System. In: Proceedings of the World Congress on Engineering and Computer Science 2017, Vol. II, WCECS 2017, San Francisco, USA, October 25-27.

-Vojnoizdavački zavod. 1970. Vojna enciklopedija.Belgrade: Vojnoizdavački zavod (in Serbian).

Wheeler, S. 2005. An Application of Queues to Offensive Support Indirect Fire Weapons Systems.Australia: Defence Science and Technology Organisation - Department of Defence. Technical Report DSTO-TR-1662.

Worthington, D., 2009. Reflections on queue modeling from the last 50 years. Journal of the Operational Research Society, 60(Issue sup1: Special Issue), S83-S92. Available at: https://doi.org/10.1057/jors.2008.178.

Yao, H., \& Ma, L. 2017. The Air Defense Missile Weapon System Based on Queuing Theory Mixed Deployment Effectiveness Evaluation. In: Proceedings of the 7th International Conference on Management, Education, Information and Control (MEICl 2017), Paris, France: Atlantis Press. Available at: https://doi.org/10.2991/meici-17.2017.174.

ПРИМЕНЕНИЕ ТЕОРИИ МАССОВОГО ОБСЛУЖИВАНИЯ В ВОЕННОЙ ОБЛАСТИ В СВЕТЕ 110-ГО ЮБИЛЕЯ

Небойша В. Николич

Университет обороны в г. Белград, Институт стратегических исследований, г. Белград, Республика Сербия

РУБРИКА ГРНТИ: 81.88.00 Материально-техническое снабжение. Логистика

ВИД СТАТЬИ: профессиональная статья ЯЗЫК СТАТЬИ: английский

Резюме:

Целью данной статьи является представление выборки примеров применения теории массового обслуживания в военной области, 8 свете 110-го юбилея создания теории массового обслуживания. B работе приведено большое количество работ отечественных авторов, опубликованных в продолжительном периоде времени, с 
целью расширения представления об этой теории и продвижения ее применения в отечественных кругах военного дела. При исследовании проблем системы массового обслуживания в военной области необходимо преодолевать специфические требования, вызывающие необходимость междисциплинарного подхода. $B$ профрессиональных кругах массового обслуживания было выявлено, что решения задач о системах массового обслуживания можно найти с помощью следующих трех методов: аналитический, численный методы и метод имитационного моделирования.

Однако следует учитывать, что не все теоретические модели массового обслуживания поддаются решению с помощью аналитического или численного методов, именно при решении таких задач необходимо применять метод имитационного моделирования.

Ключевые слова: военное применение, теория массового обслуживания, имитационное моделирование, логистика, борьба, командование и контроль, переходный режим, перенапряжение.

\section{ПРИМЕНА ТЕОРИЈЕ МАСОВНОГ ОПСЛУЖИВАҢА У ВОЈНОЈ ОБЛАСТИ НА 110. ГОДИШњИЦУ}

Небојша В. Николић

Универзитет одбране у Београду, Институт за стратегијска истраживања, Београд, Република Србија

ОБЛАСТ: логистика

ВРСТА ЧЛАНКА: стручни рад

ЈЕЗИК ЧЛАНКА: енглескИ

Сажетак:

У раду су приказани одабрани примери примене теорије масовног опслуживања у војној области, на 110. годишњицу рођења теорије масовног опслуживања. Намера је била да се пронађе и прикаже више радова домаћих аутора у дужем периоду како би се побољшала промоција будуће примене ове теорије, пре свега у домаћим војностручним круговима. У бављењу проблемима система масовног опслуживања у војној области, истраживач се суочава са специфричним захтевима који узрокују потребу за мултидисциплинарним приступом. У стручним круговима теорије масовног опслуживања препознато је да се до решења у задацима о системима масовног опслуживања може доћи на три начина: аналитички, нумерички и применом симулације. Не могу се сви теоријски модели масовног опслуживања решавати аналитички 
или применом нумеричких метода, па се за такве проблеме примењују методе симулационог моделовања.

Кључне речи: војна примена, теорија масовног опслуживања, симулација, моделовање, логистика, борба, командовање и контрола, прелазни режим, преоптерећење.

Paper received on / Дата получения работы / Датум пријема чланка: 09.07.2019. Manuscript corrections submitted on / Дата получения исправленной версии работы / Датум достављања исправки рукописа: 28.07.2019.

Paper accepted for publishing on / Дата окончательного согласования работы / Датум коначног прихватања чланка за објављивање: 30.07.2019.

(C) 2019 The Author. Published by Vojnotehnički glasnik / Military Technical Courier (www.vtg.mod.gov.rs, втг.мо.упр.срб). This article is an open access article distributed under the terms and conditions of the Creative Commons Attribution license (http://creativecommons.org/licenses/by/3.0/rs/).

() 2019 Автор. Опубликовано в «Военно-технический вестник / Vojnotehnički glasnik / Military Technical Courier» (www.vtg.mod.gov.rs, втг.мо.упр.срб). Данная статья в открытом доступе и распространяется в соответствии с лицензией «Creative Commons» (http://creativecommons.org/licenses/by/3.0/rs/).

(C 2019 Аутор. Објавио Војнотехнички гласник / Vojnotehnički glasnik / Military Technical Courier (www.vtg.mod.gov.rs, втг.мо.упр.срб). Ово је чланак отвореног приступа и дистрибуира се у складу са Creative Commons licencom (http://creativecommons.org/licenses/by/3.0/rs/).

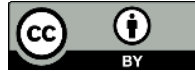

